\title{
Communication
}

[Comunicação]

\section{On the estimation of non-fibrous carbohydrates in feeds and diets}

\author{
[Sobre a estimação de carboidratos não fibrosos em alimentos e dietas] \\ E. Detmann, S.C. Valadares Filho \\ Universidade Federal de Viçosa \\ Av. PH Rolfs, s/n \\ 36570-000 - Viçosa, MG
}

From the establishment of assumptions for quantitative evaluations of feeds in the Experimental Station of Weende in the 19th Century, four groups of chemical compounds were adopted as usual laboratory analyses of feeds: ash or mineral matter (MM), crude protein (CP), crude fat or ether extract (EE), and crude fiber $(\mathrm{CF})$.

However, the quantitative evaluations of a feed must be based on assumption that its centesimal composition is entirely known. Thereby, the union of chemical compounds previously described in quantitative analyses just could be done if, and only if, their sum produced the total composition of the feed. It is obviously not verified. From this, a fifth chemical group was established, which should represent all chemical characteristics that do not belong to the other compounds. This group is calculated as:

$N F E=100-M M-C P-E E-C F$

in which NFE is the nitrogen-free extract. All terms are expressed as \% of dry matter (DM).

In a theoretical point of view, the NFE should encompass all non-nitrogen, non-fat, and nonfibrous compounds of the feed, and would be highly digestible (i.e. starch, sugars, etc). In addition, as NFE is calculated by difference (Equation 1), the sum of five chemical groups results in the total feed $(100 \%)$ and the basic assumption for quantitative analyses could be match.
The CF was supposed to measure the indigestible ballast of feeds, noticeably for non-ruminant animals. This analytical concept was based on chemical characteristics of digestion (extraction in acid simulating the stomach followed by extraction in alkali simulating the intestine) (Detmann, 2010). Nevertheless, the acid-alkali extraction causes the solubilization of hemicellulose and alkali soluble lignin (Van Soest, 1994). Thereby, the CF is theoretically formed by cellulose, alkali insoluble lignin, and residues of hemicellulose. So, much of the hemicellulose and lignin is included in NFE. This fraction (which was supposed to contain the easily digested carbohydrates) presents low and variable digestibility (Detmann, 2010) and together with underestimation of fibrous compounds constitute the main functional limitation for using $\mathrm{CF}$ and $\mathrm{NFE}$ in ruminant nutrition.

From the development of analytical concept of neutral detergent insoluble fiber (NDF) by P.J. Van Soest in the 1960's, new perspectives were generated for quantitative evaluation of ruminant feeds and diets. NDF is supposed to be the chemical approach of fiber insoluble in aqueous solutions, such as rumen environment, and corresponds to feed portion that effectively causes a fill effect in the rumen or gastrointestinal tract (Detmann, 2010). NDF is formed by cellulose, hemicellulose, and lignin, and its utilization avoids distortions caused by solubilization of fibrous compounds, such as observed in CF.

Recebido em 15 de março de 2010

Aceito em 20 de agosto de 2010

E-mail: detmann@ufv.br

Apoio: CNPq e INCT-Ciência Animal 
The replacement of CF by NDF in the evaluation of ruminant feeds constitutes a logical option to allow a broader nutritional understanding of feeds and diets. However, altering the analytical concept applied to fiber will obviously modify the understanding of chemical group estimated by difference. Thus, the NFE concept would not be applied anymore, because it must be only associated with $\mathrm{CF}$ concept.

Initially, the new "by difference" chemical group was denominated non-structural carbohydrates (Sniffen et al., 1992). However, a theoretical inconsistency was observed because pectin (a soluble fibrous compound that presents structural role in plants) would be classified as nonstructural. From this, Mertens (1997) suggested calling the new "by difference" chemical group as non-fibrous carbohydrates (NFC). His suggestion was based on the fact that such compounds cause low stimulus on masticatory activity in ruminants.

In this way, the new chemical group could be estimated as:

$N F C=100-M M-C P-E E-N D F$

However, a basic problem arrives from using Equation (2). As NFC are calculated by difference, they will encompass all errors associated with chemical compounds that are directly analyzed.

A characteristic misinterpretation is observed when urea is added in concentrates or diets. Despite of CP from urea be estimated based on Kjeldhal method assumptions $(\mathrm{N} \times 6.25)$, the high $\mathrm{N}$ content of urea causes its $\mathrm{CP}$ content be higher than its own mass $(45 \% \mathrm{~N} \times 6.25=$ $281.25 \%$ ). This CP surplus can be potentially changed in real $\mathrm{CP}$ mass from assimilation of $\mathrm{N}$ into microbial protein in the rumen. However, this does not really exist in the food and will cause underestimation of NFC content. Thus, when urea (or urea:ammoniun sulfate mixture) is used in concentrates or diets, a correction must be adopted to avoid NFC underestimation (Hall, 2000). It can be done as:

$N F C=100-M M-E E-N D F-(C P-C P u+U)$ in which $\mathrm{CPu}$ is the $\mathrm{CP}$ from urea and $\mathrm{U}$ is the urea content. All terms are expressed as \% of DM.

When diets do not contain urea, it can be noted that Equation (3) converges to Equation (2).

Under an analytical point of view, the main biases of NFC estimates are associated with NDF estimates. In general, these problems are caused by contaminants in NDF residue, which can be resultant from incorrect laboratory procedures or gravimetric contaminations inherent to the method. For all cases, overestimates of NDF contents and underestimates of NFC contents will be observed (Detmann, 2010).

The mistakes in laboratory procedures will overestimate NDF contents mainly by contamination by starch and/or influence of fat on neutral detergent action (Detmann, 2010). In the first case, the utilization of a heat-stable $\alpha$ amylase must be seen as an obligatory procedure (Mertens, 2002; Valente, 2010). On the other hand, when high-fat feeds are submitted to neutral detergent, two different phases, formed by polar and non-polar compounds, can be observed during extraction. It can lead to a migration of the detergent to non-polar phase, which is formed by fat. The neutral detergent action becomes limited on polar phase and the NDF content will be overestimated. Samples containing EE higher than $10 \%$ must be partially degreased before neutral detergent extraction (Mertens, 2002; Valente, 2010).

Gravimetrically measured fiber, such as NDF, is subjected to undesirable contaminants, which generally encompass nitrogenous compounds and ash that overestimate fiber. Thereby, NDF content only can be correctly obtained by considering the contamination by neutral detergent insoluble protein (NDIP) and ash (NDIA) (Detmann et al., 2008; Detmann, 2010).

However, current recommendations regarding corrections are controversial and not always follow a logical model. The corrected forms of NDF are:

$N D F p=N D F-N D I P$
$N D F a=N D F-N D I A$
$N D F a p=N D F-(N D I P+N D I A)$

(4), 
in which NDFp is the NDF corrected for protein, NDFa is NDF corrected for ash, and NDFap is NDF corrected for ash and protein. All terms are expressed as \% of DM.

The NDF corrected for protein (NDFp; Equation 4) was adopted by Hall (2000) to estimate NFC, including diets which urea is added. However, a chemical inconsistency is observed because NDIA is a part of MM. Thereby, the omission of ash correction will cause a double subtraction of NDIA during NFC estimation. To demonstrate this, the Equation (2) can be re-written using two assumptions: 1. NDF does have ash contaminant besides protein contaminant; and 2. the MM of feed can be divided in portions that are soluble and insoluble in neutral detergent. Assuming these and using Equations (2) and (4), it can be done:

$N F C=100-(N D S A+N D I A)-C P-E E-N D F p$ (7a), $N F C=100-(N D S A+N D I A)-C P-E E-(N D F a p+N D I A) \quad(7 \mathrm{~b})$, in which NDSA is neutral detergent soluble ash (\% of DM).

Rearranging the terms of Equation (7a):

$N F C=100-N D S A-N D I A-C P-E E-N D I A-N D F a p$ $N F C=100-N D S A-2 \times N D I A-C P-E E-N D F a p$

(7c), (7d),

So, if the ash correction is not considered, the NFC content will present a negative bias that is equivalent to NDIA content (Table 1).

In addition, the NDFp was suggested by Nutrient... (2001) to estimate energy content of cattle feeds and diets. However, once more there is a nutritional inconsistency (besides NFC underestimation) because ash does not produce energy (Detmann et al., 2008). So, the correct utilization of NDF in energy prediction models must take into account the contaminant ash.

Table 1. Theoretical example of non-fibrous carbohydrates estimation using different approaches to NDF

\begin{tabular}{|c|c|c|}
\hline Item & \multicolumn{2}{|c|}{ Content $^{1}$} \\
\hline Mineral matter & \multicolumn{2}{|r|}{5.0} \\
\hline Crude protein & \multicolumn{2}{|r|}{21.5} \\
\hline Ether extract & \multicolumn{2}{|r|}{3.8} \\
\hline Neutral detergent fiber (NDF) & \multicolumn{2}{|r|}{20.3} \\
\hline Neutral detergent insoluble protein (NDIP) & \multicolumn{2}{|r|}{3.4} \\
\hline Neutral detergent insoluble ash (NDIA) & \multicolumn{2}{|r|}{1.5} \\
\hline Neutral detergent fiber $a^{2}(\mathrm{NDFa})$ & \multicolumn{2}{|r|}{18.8} \\
\hline Neutral detergent fiber $\mathrm{p}^{2}$ (NDFp) & \multicolumn{2}{|r|}{16.9} \\
\hline Neutral detergent fiber $a^{2}$ (NDFap) & \multicolumn{2}{|r|}{15.4} \\
\hline & Estimate & Bias \\
\hline Non-fibrous carbohydrates (using NDF) & 49.4 & -4.9 (NDIP plus NDIA) \\
\hline Non-fibrous carbohydrates (using NDFa) & 50.9 & -3.4 (NDIP) \\
\hline Non-fibrous carbohydrates (using NDFp) & 52.8 & -1.5 (NDIA) \\
\hline Non-fibrous carbohydrates (using NDFap) & 54.3 & - \\
\hline
\end{tabular}

$1 \%$ of DM. ${ }^{2}$ a and $\mathrm{p}$ indicate corrections for ash and protein, respectively.

On the other hand, an official NDF analytical method was recently adopted by the Association of Official Analytical Chemists - AOAC (Mertens, 2002). In that method, only correction for ash was considered (NDFa; Equation 5). Assuming that $\mathrm{CP}$ of a feed can be fractionated into neutral detergent soluble and insoluble portions and using Equations (2) and (5), it can be done:

$N F C=100-M M-(N D S P+N D I P)-E E-N D F a$ $N F C=100-M M-N D S P-N D I P-E E-(N D F a p+N D I P)(8 \mathrm{~b})$, $N F C=100-M M-N D S P-2 \times N D I P-E E-N D F a p \quad(8 \mathrm{c})$, in which NDSP is the neutral detergent soluble protein $(\%$ of $\mathrm{DM})$.

In this way, using NDFa underestimates NFC content because NDIP is doubly subtracted (Table 1).

The AOAC method did not take into account that major contaminant of gravimetrically measured fiber is protein (Van Soest, 1994). Despite of inclusion of sodium sulfite in neutral detergent (Mertens, 2002), it must be emphasized this compound does not remove all contaminant protein. In addition, sodium sulfite can extract 
part of the lignin (Van Soest et al., 1991) and its use has not been recommended in Brazil (Detmann et al., 2010).

Additionally, if corrections for ash and protein are not considered, there will be biases on individual digestibility coefficients of NDF and NFC (Chizzotti et al., 2007). Thereby, the NDF corrected for ash and protein (NDFap; Equation 6) must be used to estimate NFC. This form was adopted by current Brazilian model for estimating energy value of cattle diets based on chemical composition of feeds (Detmann et al., 2010).

After all, when concentrates or diets containing urea are evaluated, the NFC must be estimated by:

$$
N F C=100-M M-E E-N D F a p-(C P-C P u+U) \quad(9),
$$

When urea is not used, Equation (9) converges to:

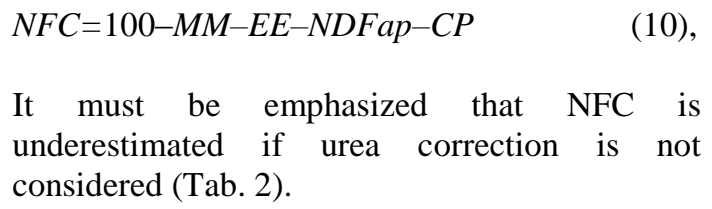
underestimated if urea correction is not considered (Tab. 2).

On the other hand, when using urea correction it can be observed that the sum of chemical compounds does not produce $100 \%$ (Table 2; $\mathrm{MM}+\mathrm{CP}+\mathrm{EE}+\mathrm{NDFap}+\mathrm{NFC}=103.2 \%)$. Nevertheless, it must not be considered bias but just a reflex of correct understanding of food.

Table 2. Theoretical example of NFC estimation in a diet containing urea

\begin{tabular}{|c|c|c|}
\hline Item & \multicolumn{2}{|c|}{ Content $^{1}$} \\
\hline Mineral matter & \multicolumn{2}{|c|}{6.0} \\
\hline Crude protein $(\mathrm{CP})$ & \multicolumn{2}{|c|}{13.2} \\
\hline Urea: ammonium sulfate $(9: 1)(\mathrm{U})$ & \multicolumn{2}{|c|}{2.0} \\
\hline Crude protein from urea $(\mathrm{CPu})^{2}$ & \multicolumn{2}{|c|}{5.2} \\
\hline Ether extract & \multicolumn{2}{|c|}{2.6} \\
\hline Neutral detergent fiber ap (NDFap) ${ }^{3}$ & \multicolumn{2}{|c|}{40.5} \\
\hline & Estimate & Bias \\
\hline Non-fibrous carbohydrates (not considering urea) & 37.7 & $-3.2(\mathrm{CPu}-\mathrm{U})$ \\
\hline Non-fibrous carbohydrates (considering urea) & 40.9 & - \\
\hline
\end{tabular}

$1 \%$ of DM. ${ }^{2}$ Assuming $260 \%$ of CP in urea:ammonium sulfate mixture. ${ }^{3}$ ap indicates corrections for ash and protein.

Keywords: food analyses, neutral detergent fiber, proximal system

\section{RESUMO}

Os carboidratos não fibrosos (CNF) contemplam a fração dos alimentos com elevada capacidade de produção de energia, destacando-se o amido, os açúcares, a pectina, etc. Por constituir a porção do alimento estimada pela diferença entre o todo a as partes avaliadas analiticamente (proteína bruta, matéria mineral, extrato etéreo e fibra em detergente neutro), o teor de CNF tende a absorver os erros cometidos na avaliação de cada parte. Aspectos da estimação do teor de CNF em alimentos e dietas são apresentados e discutidos.

Palavras-chave: análise de alimentos, fibra em detergente neutro, sistema proximal

\section{REFERENCES}

CHIZZOTTI, M.L.; VALADARES FILHO, S.C.; VALADARES, R.F.D. et al. Consumo, digestibilidade e excreção de ureia e derivados de purinas em vacas de diferentes níveis de produção de leite. Rev. Bras. Zootec., v.36, p.138-146, 2007.
DETMANN, E. Fibra na nutrição de novilhas leiteiras. In: PEREIRA, E.S.; PIMENTEL, P.G.; QUEIROZ, A.C. et al. (Eds). Novilhas leiteiras. Fortaleza: Graphiti, 2010. p.253-302.

DETMANN, E.; VALADARES FILHO, S.C.; PINA, D.S. et al. Prediction of the energy value of cattle diets based on chemical composition of the feeds under tropical conditions. Anim. Feed Sci. Technol., v.143, p.124-147, 2008. 
DETMANN, E.; VALADARES FILHO, S.C.; PAULINO, M.F. Prediction of the energy value of cattle diets based on chemical composition of the feeds. In: VALADARES FILHO, S.C.; MARCONDES, M.I.; CHIZZOTTI, M.L. et al. (Eds). Nutrient requirements of zebu beef cattle BR-Corte. 2.ed. Viçosa: UFV, 2010. p.45-60.

HALL, M.B. Neutral detergent-soluble carbohydrates. Nutritional relevance and analysis. Gainesville: University of Florida, 2000. 76p.

MERTENS, D.R. Creating a system for meeting the fiber requirements of dairy cows. J. Dairy Sci., v.80, p.1463-1481, 1997.

MERTENS, D.R. Gravimetric determination of amylase treated neutral detergent fiber in feeds with refluxing in beaker or crucibles: collaborative study. J. AOAC Intern., v.85, p.1217-1240, 2002.

NUTRIENT requirements of dairy cattle. 7.ed. Washington: Academic, 2001. 381p.
SNIFFEN, C.J.; O'CONNOR, A.C.; VAN SOEST, P.J. et al. A net carbohydrate and protein system for evaluating cattle diets: II Carbohydrate and protein availability. J. Anim. Sci., v.70, p.3562-3577, 1992.

VALENTE, T.N.P. Utilização de tecidos na avaliação de compostos fibrosos e na degradação ruminal in situ de alimentos para ruminantes. 2010. 90f. Tese (Doutorado em Zootecnia) - Universidade Federal de Viçosa, Viçosa.

VAN SOEST, P.J. Nutritional ecology of the ruminant. 2.ed. Ithaca: Cornell University, 1994. 476p.

Van SOEST, P.J.; ROBERTSON, J.B.; LEWIS, B.A.S. Methods for dietary fiber, neutral detergent fiber, and non-starch polysaccharides in relation to animal nutrition. J. Dairy Sci., v.74, p.3583-3597, 1991. 